\title{
Implementasi Model Pembelajaran Blended Learning di TKIT Al Fatah
}

\author{
Iis Dewi Lestari \\ Teknik Informatika, Universitas Indraprasta PGRI, Indonesia. \\ iisdewi_lestari@yahoo.co.id
}

\begin{abstract}
Abstrak
Banyak tantangan dan permasalahan yang dihadapi pada saat pembelajaran online di masa pandemi, seperti kurangnya minat siswa. Model blended learning merupakan salah satu alternatif pembelajaran selama pandemi. Tujuan penelitian ini adalah untuk mengetahui bagaimana implementasi model blended learning di TKIT Al Fatah. Metode penelitian ini adalah deksriptif kualitatif. Subjek penelitian ini adalah guru dan siswa TKIT Al Fatah dan objek penelitian ini adalah Implementasi Blended Learning di TKIT AL Fatah. Sampel dari penelitian ini adalah menggunakan snaw ball sampling yaitu guru dan siswa di kelas TK B. Teknik analsis data dilakukan dengan reduksi data, penyajian data dan penarikan kesimpulan. Teknik pengumpulan data yang dilakukan adalah observasi lapangan, wawancara dan dokumentasi. Simpulan dari hasil penelitian ini adalah 1) implementasi blended learning di TKIT AL Fatah menggabungkan model pembelajaran online (zoom meeting, whatsapp group dan youtube) serta menggunakan pembelajaran tatap muka terbatas yang terbagi menjadi dua sesi setiap pertemuannya, 2) Pemilihan media pembelajaran zoom meeting, whatsappgroup dan youtube untuk pembelajaran online berdasarkan kesepakatan orang tua murid dan pihak sekolah, 3) Pembelajaran tatap muka terbatas pada siswa berjalan sesuai dengan aturan dan siswa sangat antusias mengikuti pembelajaran di kelas.
\end{abstract}

Kata kunci: blended learning, implementasi, model pembelajaran.

Dikirim: 17 Oktober 2021

Direvisi: 31 Oktober 2021

Diterima: 25 November 2021

Identitas Artikel:

Lestari, I. D. (2022). Implementasi Blended Learning di TKIT Al Fatah. Jurnal Ilmu Pendidikan (JIP) STKIP Kusuma Negara, 13(2), 120-127.

\section{PENDAHULUAN}

Proses pembelajaran sejak adanya pandemi COVID-19 di Indonesia, tentunya sangat berpengaruh dengan seluruh kegiatan pembelajaran di Indonesia dari mulai bangku Taman kanak-kanak sampai dengan perguruan tinggi. Hal ini sejalan dengan proses kegiatan pembelajaran yang semua sekolah menggunakan e learning sebagai alternatif model pembelajaran di masa pandemi. Tentunya tidak mudah menggunakan media pembelajaran e learning bagi siswa di bangku Taman kanakkanak. Banyak tantangan dan permasalahan yang dihadapi pada saat pembelajaran online diterapkan di bangku Taman kanak-kanak. Siswa cenderung bosan untuk berdiam diri di depan layar dalam waktu lama, sehingga orang tua kesulitan dalam mendampingi anak di bangku TK untuk melakukan pembelajaran online yang pada dasarnya anak-anak usia 5-6 tahun di bangku TK memiliki kecenderungan siswa yang aktif dan berkreasi dan sulit untuk berdiam diri berlama-lama di depan layar. Pembelajaran dengan menggunakan ragam media pembelajaran online mulai dari 
Google Meet, Zoom, Whatsapp Group (WAG), Youtube digunakan sebagai alternatif pembelajaran selama pandemi COVID-19.

Ragam alternatif pembelajaran online digunakan oleh guru dan siswa di era pandemi dengan penyesuaian pembelajaran online baik oleh guru maupun siswa. Guru mau tidak mau harus meningkatkan kualitas dalam pembelajaran online, guru dituntut dapat mengoperasikan ragam media pembelajaran online. Orang tua murid pun mau tidak mau harus mendalami ragam aplikasi media pembelajaran untuk mendampingi belajar anak di rumah.

Kombinasi media pembelajaran digunakan oleh TKIT Al Fatah untuk mencari alternatif dari kegiatan pembelajaran yang terbaik bagi siswa dan guru di masa pandemi yaitu dengan menggunakan media pembelajaran WAG, zoom dan digabungkan dengan pembelajaran tatap muka terbatas. Dengan pelaksanaan blended learning diharapkan siswa dapat jauh lebih semangat, fokus dan termotivasi dalam kegiatan pembelajaran di masa pandemi. Hal ini tentunya menjadi alternatif terbaik agar tujuan pembelajaran dapat tercapai sebagaimana mestinya. Dari latar belakang di atas maka dapat dirumuskan masalah: Bagaimana implementasi blended learning di TKIT Al Fatah?

Wardani, Toenlioe dan Wedi (2018) dalam hasil penelitiannya dikatakan bahwa metode pembelajaran blended learning merupakan media pembelajaran yang dapat menarik minat dan perhatian bagi siswa untuk mengatasi kejenuhan dengan menggabungkan proses pembelajaran online dan tatap muka. Kemajuan teknologi saat ini sangat berpengaruh pada perilaku dan kebiasaan manusia sehingga tidak dapat dihindari dalam proses pembelajaran. Pembelajaran blended learning dapat meningkatkan hasil belajar siswa serta meningkatkan hubungan tiga komunikasi dalam blended learning yaitu face to face, offline dan online. Model pembelajaran blended learning merupakan kombinasi antara pembelajaran konteks online dan offline (Idris, 2018).

Tujuan penelitian ini adalah untuk mengetahui bagaimana pelaksanaan blended learning di TKIT Alfatah, dari pemilihan media online yang digunakan dan untuk mengetahui bagaimana pelaksanaan pada saat tatap muka atau offline. Serta untuk mengetahui bagaimana blended learning dapat digunakan dengan baik di TKIT Al Fatah.

\section{Model Pembelajaran Blended Learning}

Hartono, Saputro dan Fitriawan (2019) dalam hasil penelitiannya menyatakan bahwa model pembelajaran adalah cara guru untuk memfasilitasi proses belajar kepada siswa, guru memberikan arahan untuk mengarahkan siswa dalam mengemukakan pendapat, ide, dan kreativitas, sehingga guru diharapkan menjadi fasilitator yang baik. Guru tentunya harus mengetahui kebutuhan dan latar belakang siswa serta dukungan dari fasilitas dan media yang dapat dimanfaatkan oleh guru dalam memilih model pembelajaran yang akan digunakan dalam proses pembelajaran.

Dalam hasil penelitiannya Fahrulliah dan Turdjai (2019) menyimpulkan bahwa model blended learning dapat menumbuhkan kemandirian siswa dan meningkatkan prestasi hasil belajar siswa. Hal ini dapat dilihat bahwa siswa secara mandiri dapat belajar dengan mendapatkan informasi baik dari web maupun pada saat video conference. Melalui blended learning, siswa dilibatkan pula secara aktif pada saat 
tatap muka sehingga perpaduan pembelajaran dapat bervariasi dan meningkatkan prestasi hasil belajar siswa.

Model pembelajaran blended learning merupakan pelengkap dari penggunaan e-learning dikarenakan dibutuhkannya umpan balik interaksi dua arah antara guru dan siswa, sehingga kekurangan dalam e-learning dapat disempurnakan dengan tatap muka (Hartono dkk, 2019). Blended learning merupakan model pembelajaran dimana siswa dapat mengakses materi secara online lalu didiskusikan secara bersama dalam kelas baik secara online maupun tatap muka (Manggabarani, Sugiarti \& Masri, 2016). Tentunya model pembelajaran blended learning sangat tepat digunakan dimasa pandemi dan transisi dengan butuh banyak penyesuaian baik itu dari guru, siswa maupun orang tua murid. Dengan blended learning dapat memecahkan permasalahan yang terjadi terkait kegiatan belajar mengajar di masa pandemi, melalui blended learning, guru dan siswa dapat memilih dan menggabungkan kegiatan pembelajaran offline dan online sehingga kebutuhan siswa dalam belajar di masa pandemi dapat teratasi.

\section{METODE PENELITIAN}

Metode penelitian ini adalah deksriptif kualitatif. Subjek penelitian ini adalah guru dan siswa TKIT Al Fatah dan objek penelitian ini adalah Implementasi Blended Learning di TKIT AL Fatah. Dalam objek penelitian dapat dilihat bagaimana guru dan siswa pada saat melaksanakan model pembelajaran blended learning dan media yang digunakan. Metode kualitatif adalah penelitian yang menghasilkan data berupa lisan orang dan perilaku yang sedang diamati, meneliti suatu objek dengan tujuan untuk membuat deskriptif (Suparmo, 2017). Teknik analsis data dilakukan dengan pengumpulan data, reduksi data dan penyajian data dan penarikan kesimpulan. Pada saat reduksi data artinya merangkum untuk memilah hal-hal yang pokok untuk memfokuskan pada pelaksanaan blended learning di lokasi tersebut. Dalam mereduksi data maka peneliti merangkum hal pokok dari hasil wawancara maupun kejadian yang ada di lokasi. Teknik pengumpulan data yang dilakukan adalah observasi lapangan, wawancara dan dokumentasi. Pada saat observasi lapangan maka peneliti terjun langsung ke sekolah untuk melihat dan mengamati guru saat pembelajaran online, serta ke lokasi beberapa siswa pada saat menerima pembelajaran online. Selain itu peneliti, mengunjungi dan mengamati secara langsung pada saat kegiatan tatap muka terbatas di dalam kelas. Wawancara dilakukan kepada guru kelas TK B yaitu Ibu Yuni dan Ibu Nur serta wawancara kepada orang tua murid yaitu Mama Kendra dan Mama Zee dan kepala sekolah TK Al Fatah yaitu Ibu Susi. Dokumen dalam penelitian ini yaitu mencatat segala peristiwa yang terjadi di lapangan dan foto.

\section{HASIL DAN PEMBAHASAN}

Hasil penelitian yang dilakukan Juli-Oktober 2021 di TKIT AL Fatah, bahwa implementasi metode blended learning dilakukan dengan menggabungkan pembelajaran online dan pembelajaran tatap muka terbatas.

Proses pembelajaran online yang banyak dikeluhkan oleh siswa dan orang tua murid tentunya dapat menghambat tujuan pendidikan dikarenakan ragam kendala dan permasalahan yang dihadapi oleh guru, siswa dan orang tua murid. Berdasarkan 
Peraturan walikota Depok No.66 tahun 2021 tentang Pedoman penyelenggaraan tatap muka terbatas di masa pandemi corona virus disease cukup membuat siswa dan orang tua murid senang tentunya dapat melakukan pembelajaran tatap muka terbatas. Sehingga penggabungan pembelajaran tatap muka dan e learning menjadi alternatif dalam pembelajaran selama pandemi COVID-19 yaitu menggunakan metode blended learning. Pembelajaran blended learning merupakan pembelajaran yang menggabungkan teori belajar kognitif dan konstruktivis. Pengetahuan diambil oleh peserta didik melalui interaksinya dengan lingkungan (Asmendri \& Sari, 2018). Sehingga melalui metode pembelajaran blended learning dapat menumbuhkan kemampuan kognitif dan sosialisasi interaksi antar lingkungan sekitar.

Berdasarkan observasi atau pengamatan dapat diketahui bahwa siswa pada saat menggunakan pembelajaran online tentunya membutuhkan pendampingan dari orang tua karena siswa di bangku TK belum mampu mengoperasionalkan aplikasi zoom dan wag. Oleh karena itu, keluhan yang dihadapi orang tua murid adalah mengontrol anak untuk tetap fokus pada layar selama kegiatan zoom berlangsung selama 1-2 jam. Siswa hanya bisa fokus sekitar 45 menit saja, selebihnya orang tua murid menyatakan butuh kesabaran dalam mendampingi anak selama zoom berlangsung.

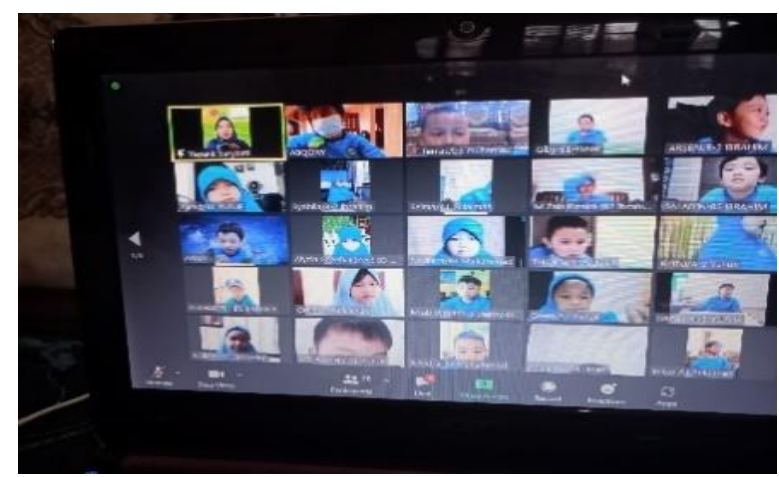

Gambar 1. Pembelajaran online pada saat menggunakan zoom meeting

Kegiatan pembelajaran melalui zoom di TKIT AL Fatah dilakukan tiga hari dalam seminggu yaitu Senin, Rabu dan Kamis. Keberlangsungan penggunaan zoom cukup ekeftif dan menjadi alternatif pemecahan masalah di masa pandemi untuk memberikan kualitas pembelajaran kepada siswa. Hal ini senada dengan hasil penelitian (Monica \& Fitriawati, 2020) yang menyatakan bahwa aplikasi zoom sangat efektif digunakan sebagai media pembelajaran pada masa pandemi, banyaknya fitur yang ditampilkan oleh zoom dapat menarik minat siswa untuk belajar meskipun kuota belajar internet menjadi semakin besar. Siswa di TKIT Al Fatah pada saat belajar menggunakan zoom cukup antusias, hanya saja terkadang terkendala jaringan internet. Di sisi lain, guru-guru di TKIT AL Fatah sudah mampu mengoperasionalkan zoom sehingga dapat menjaga keefektifan pembelajaran pada saat menggunakan zoom. 


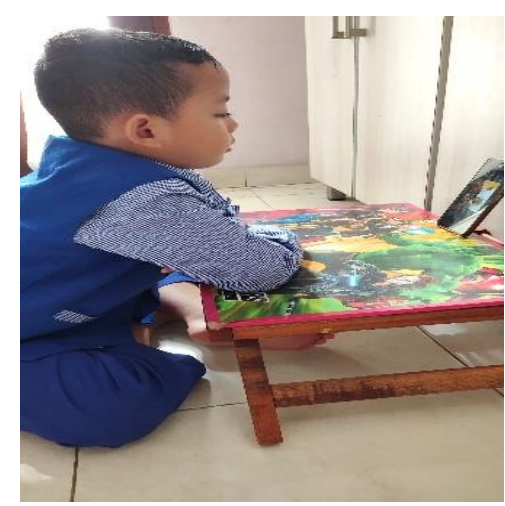

Gambar 2. Kegiatan pembelajaran videocall dari WAG antara guru dan siswa

Selain menggunakan zoom, pembelajaran online di TKIT Al Fatah memanfaatkan WAG untuk memberikan informasi, terkait materi maupun jadwal mata pelajaran, tugas siswa dan segala yang berhubungan dengan pembelajaran. Kegiatan video call dilakukan untuk mendapatkan interaksi dua arah antara guru dan siswa lebih pribadi sehingga guru dapat mengenal siswa jauh lebih dalam. Pada saat video call, guru dapat mengetahui sejauh mana pemahaman materi yang dipahami oleh siswa selama proses pembelajaran berlangsung. Hal ini senada dengan yang disampaikan Rahartri (2019) dalam hasil penelitiannya bahwa whatsapp merupakan aplikasi yang sangat sederhana, hemat baterai dan dapat memberikan informasi dengan cepat melalui foto, dokumen maupun telpon dan videocall. Whatsapp merupakan aplikasi yang ringan dan mudah digunakan serta sangat efektif dalam pemberian jasa informasi.

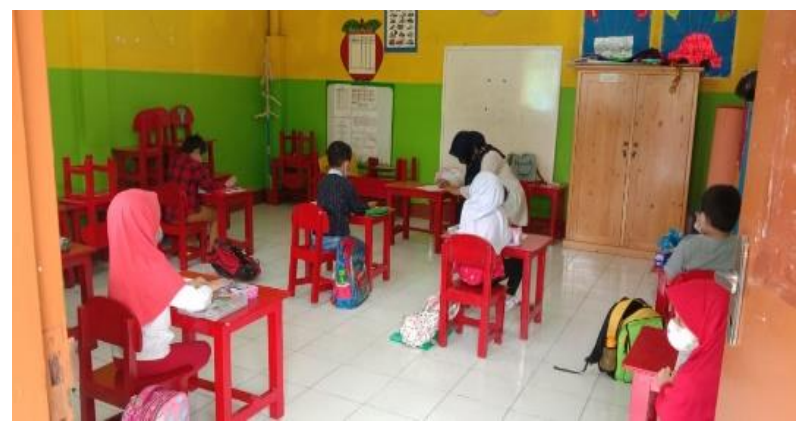

Gambar 3. Kegiatan pembelajaran tatap muka terbatas (offline) di kelas TKIT AL Fatah

Implementasi blended learning dilakukan dengan mengombinasikan WAG, youtube, zoom secara online dan pembelajaran tatap muka terbatas. Hal ini dilakukan untuk menyempurnakan kekurangan yang ada pada saat menggunakan pembelajaran secara online. Pembelajaran online memiliki kekurangan pada pelaksanaannya yaitu sulit mendapatkan interaksi umpan balik yang cepat antara guru dan siswa, hal ini dapat disebabkan dari jaringan internet yang bermasalah, pendukung micropohone atau audio yang bermasalah sehingga kurang mendapatkan interaksi yang cepat. Untuk memperbaiki kekurangan tersebut oleh karena itu implementasi blended learning di TKIT AL Fatah dilakukannya pembelajaran tatap muka terbatas, tentunya dengan tatap muka guru dan siswa akan 
lebih cepat mendapatkan umpan balik dalam berinteraksi. Siswa dapat lebih bersosialisasi dengan guru dan siswa dan mengenal lingkungan sekitar. Kombinasi model pembelajaran blended learning di TKIT Al Fatah dapat dikatakan berhasil ditengah pembelajaran pandemi COVID-19. Guru dapat mengombinasikan model pembelajaran disesuaikan dengan keadaan dan kebutuhan siswa.

Tabel 1. Jadwal Pembelajaran Tatap Muka Terbatas Kelas B3 Muhammad

\begin{tabular}{|c|c|c|}
\hline & \multicolumn{2}{|c|}{ Sesi } \\
\hline & I & II \\
\hline Waktu & $08.00-09.30$ & $09.30-11.00$ \\
\hline Hari & Selasa dan Jumat & Selasa dan Jumat \\
\hline Nama Guru & Ibu Yuni & Ibu Nur \\
\hline Nama Siswa & $\begin{array}{l}\text { Ibna } \\
\text { Zee } \\
\text { Kendra } \\
\text { Alesa } \\
\text { Gibran } \\
\text { Ghaza } \\
\text { Irsyad } \\
\text { Nadhira } \\
\text { Al }\end{array}$ & $\begin{array}{l}\text { Aisyah } \\
\text { Abigail } \\
\text { Vano } \\
\text { Raffa } \\
\text { Dzafran } \\
\text { Faras }\end{array}$ \\
\hline
\end{tabular}

Pembelajaran blended learning di TKIT Al Fatah menggabungkan pembelajaran tatap muka terbatas dengan WAG, youtube dan zoom meeting. Penggabungan model pembelajaran ini dilakukan secara efektif karena sesuai dengan kebutuhan orang tua murid dan siswa. Orang tua murid dan siswa membutuhkan pembelajaran tatap muka terbatas untuk mendapatkan sosialisasi secara langsung dengan teman-temannya, interaksi dengan guru dan lingkungan sekolah. Meskipun dilakukan secara bertahap dan diberikan sesi dengan jumlah batas siswa 5-6 siswa di kelas namun pembelajaran tatap muka terbatas berjalan dengan efektif karena adanya kerjasama antar guru, siswa dan orang tua murid. Pembelajaran online melalui WAG, yang diberikan untuk informasi tugas dan melakukan video call. Zoom dilakukan untuk diberikan penjelasan melalui layar oleh guru. Siswa diwajibkan untuk mengaktifkan kamera agar guru tetap dapat mengontrol siswa meskipun dari layar.

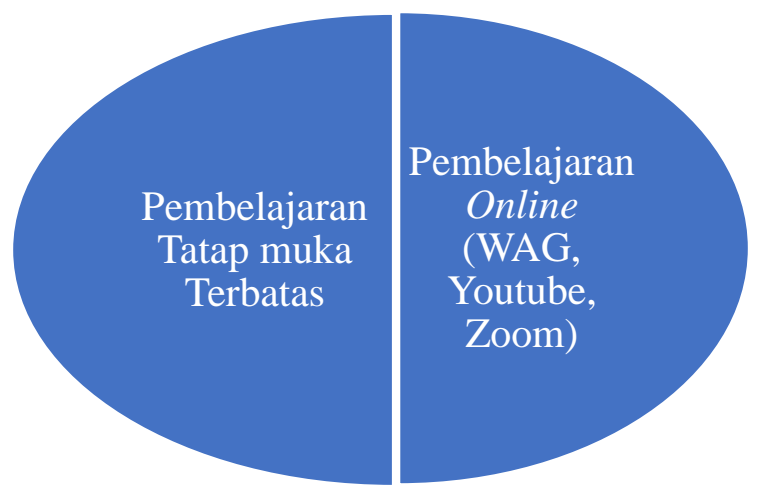

Gambar 4. Implementasi model pembelajaran Blended Learning yang digunakan oleh TKIT Al Fatah 
Dengan menggabungkan model pembelajaran ini maka implementasi blended learning sangat tepat diterapkan di TKIT Al Fatah. Siswa dan guru sangat antusias menggunakan media pembelajaran blended learning yang dapat dilihat dari kehadiran setiap pembelajaran, siswa sangat interaktif dan antusias melaksanakan tugas yang diberikan oleh guru. Hal ini juga didukung oleh Talizaro menyatakan bahwa untuk meningkatkan minat peserta didik maka dibutuhkan media pembelajaran yang tepat untuk digunakan dengan sinergis dan guru harus mampu mengoptimalkan media pembelajaran yang digunakan (Talizaro, 2018).

Berdasarkan hasil wawancara dengan guru kelas TK B yaitu Ibu Nur menyampaikan bahwa blended learning dilakukan karena kondisi yang terdesak di tengah pandemi. Guru dituntut mampu membuat video untuk ditayangkan di youtube sebagai bahan pembelajaran, serta guru dituntut mampu menggunakan zoom meeting untuk melakukan pembelajaran online. Namun menurut Ibu Yuni selaku guru kelas TK B juga menyampaikan adanya beberapa kendala yang dihadapi pada saat online yaitu jaringan, microphone yang tidak jelas terdengar sehingga menghambat proses pembelajaran pada saat online. Oleh karena itu berdasarkan hasil wawancara dengan orang tua murid Mama Kendra dan Mama Zee menyarankan kepada pihak sekolah sebaiknya dilakukan PTMT agar siswa dapat mengenal lebih dekat guru dan teman-temannya karena tatap muka bagi siswa TK dirasa penting dan sangat membantu tumbuh kembang anak.

\section{SIMPULAN}

Simpulan dari hasil penelitian ini adalah bahwa implementasi model pembelajaran blended learning merupakan pilihan alternatif yang tepat dalam melakukan kegiatan pembelajaran di masa pandemi untuk siswa di TKIT Al Fatah. Penggabungan pelaksanaan tatap muka terbatas dan pembelajaran online melalui zoom dan WAG serta youtube dapat berjalan selaras dengan harapan dari para guru dan siswa sehingga tujuan pembelajaran dapat tercapai. Pelaksanaan zoom dilakukan pada saat tidak melakukan tatap muka terbatas ke sekolah yaitu pada hari Senin, Rabu dan Kamis. Sedangkan kegiatan tatap muka terbatas dilakukan dua hari yaitu Selasa dan Jumat, dengan pembagian sesi di kelas hanya terdapat 6 siswa dan 1 guru. Model blended learning sangat tepat digunakan pada masa pandemi, disisi lain kemajuan teknologi terpacunya semua orang tua murid dan guru dalam mengoperasionalkan pembelajaran online semakin dekat dan bersahabat. Disisi lain, proses tatap muka dilakukan dapat menumbuhkan kedekatan personal antara guru dan siswa serta sesama siswa. Implementasi blended learning di TKIT AL Fatah menggabungkan model pembelajaran online (zoom meeting, WAG, dan youtube) serta menggunakan pembelajaran tatap muka terbatas yang terbagi menjadi dua sesi setiap pertemuannya. Hasil wawancara kepada Ibu Yuni dan Ibu Nur sebagai guru kelas yang menyatakan bahwa tugas lembar kerja siswa dapat diselesaikan dengan tuntas oleh semua siswa, serta kehadiran siswa pada saat tatap muka terbatas mencapai maksimal kehadiran. Serta berdasarkan hasil wawancara orang tua murid yaitu Mama Kendra dan Mama Zee sebagai orang tua murid menyampaikan bahwa anak-anak sangat senang dan bisa mengikuti pembelajaran dengan proses pembelajaran yang menggunakan zoom dan tatap muka terbatas ke sekolah. Pemilihan media pembelajaran zoom meeting, WAG dan youtube untuk 
pembelajaran online berdasarkan kesepakatan orang tua murid dan pihak sekolah, guru dapat melakukan inovasi dan mencari solusi dari permasalahan yang dihadapi oleh siswa dalam kesulitan pembelajaran selama pandemi melalui model pembelajaran blended learning. Pembelajaran tatap muka terbatas berjalan sesuai dengan aturan dan kesepakatan antara orang tua murid dan pihak sekolah dengan tetap dijalankan sesuai prokes.

\section{REFERENSI}

Asmendri, A., \& Sari, M. (2018). Analisis Teori-Teori Belajar pada Pengembangan Model Blended Learning dengan facebook (MBL-FB). Natural Science: Jurnal Penelitian Bidang IPA dan Pendidikan IPA, 4(2), 604-615. http://dx.doi.org/10.15548/nsc.v4i2.449

Fahrulliah, A., \& Turdjai, T. (2019). Application of blended learning models to improve learning independence and achievement. Jurnal ilmiah teknologi pendidikan, 9(2), 101-111. http://dx.doi.org/10.33369/diadik.v9i2.17438

Hartono, H., Saputro, M., \& Fitriawan, D. (2019). Penerapan model pembelajaran blended learning pada mata kuliah logika dan penalaran matematika. JPMI (Jurnal Pendidikan Matematika Indonesia), 4(2), 84-89. http://dx.doi.org/10.26737/jpmi.v4i2.849

Idris, H. (2018). Pembelajaran model blended learning. Jurnal Ilmiah Iqra', 5(1). http://dx.doi.org/10.30984/jii.v5i1.562

Manggabarani, A. F., Sugiarti, S., \& Masri, M. (2016). Pengaruh model pembelajaran blended learning terhadap motivasi dan hasil belajar siswa kelas X SMA Negeri 1 Pitumpanua Kab. Wajo (studi pada materi pokok sistem periodik unsur). Chemica: Jurnal Ilmiah Kimia dan Pendidikan Kimia, 17(2), 83-93. https://doi.org/10.35580/chemica.v17i2.4688

Monica, J., \& Fitriawati, D. (2020). Efektivitas Penggunaan Aplikasi Zoom Sebagai Media Pembelajaran Online Pada Mahasiswa Saat Pandemi COVID-19. Jurnal Communio: Jurnal Jurusan Ilmu Komunikasi,9(2), 1630-1640. https://doi.org/10.35508/jikom.v9i2.2416

Rahartri, R. (2019). "Whatsapp" media komunikasi efektif masa kini (Studi kasus pada layanan jasa informasi ilmiah di kawasan PUSPIPTEK. Visi Pustaka: Buletin Jaringan Informasi Antar Perpustakaan, 21(2), 147-156.

Suparmo, L. (2017). Semiotics in Signs, Symbols and Brands (Semiotika dalam "tanda", simbol dan merek). Inter Komunika: Jurnal Komunikasi, 2(1), 71-81. http://dx.doi.org/10.33376/ik.v2i1.20

Tafonao, T. (2018). Peranan media pembelajaran dalam meningkatkan minat belajar mahasiswa. Jurnal Komunikasi Pendidikan,2(2), 103-114. https://doi.org/10.32585/jkp.v2i2.113

Wardani, D. N., Toenlioe, A. J., \& Wedi, A. (2018). Daya tarik pembelajaran di era 21 dengan Blended Learning. Jurnal Kajian Teknologi Pendidikan, 1(1), 13-18. 